\title{
Genetic Characterization of Barley Net Blotch Resistance Genes
}

Patrick D. O’Boyle, Betaseed, Inc., Shakopee, MN 55379; Wynse S. Brooks, Department of Crop and Soil Environmental Sciences, Virginia Polytechnic Institute and State University, Blacksburg 24061; Brian J. Steffenson, Department of Plant Pathology, University of Minnesota, St. Paul 55108; and Erik L. Stromberg, Department of Plant Pathology, Physiology, \& Weed Science, and Carl A. Griffey, Department of Crop and Soil Environmental Sciences, Virginia Polytechnic Institute and State University, Blacksburg

\begin{abstract}
O’Boyle, P. D., Brooks, W. S., Steffenson, B. J., Stromberg, E. L., and Griffey, C. A. 2011. Genetic characterization of barley net blotch resistance genes. Plant Dis. 95:19-23.

Net blotch, caused by Pyrenophora teres f. teres, is one of the most devastating diseases of barley (Hordeum vulgare). Efficient utilization of available resistance sources is dependent upon successful characterization of genes conditioning resistance in diverse sources. Five netblotch-resistant parents and one susceptible parent were intercrossed to identify novel resistance genes and postulate gene number and mode of inheritance. Seedling response to isolate ND89-19 was evaluated in a greenhouse test. Results indicate that the resistant spring barley lines

single dominant genes for resistance. Resistance in CIho 5098 is governed by the same dominant gene conferring resistance in Nomini. Resistance in CIho 2291 is controlled by one dominant gene which, putatively, is the same gene conferring resistance in ND B112 but differs from the resistance genes carried by the other parents in this study. The resistance gene in Nomini or Clho 5098 could be pyramided with the resistance gene in Clho 2291 or ND B112 to enhance the durability of resistance against a wide spectrum of $P$. teres isolates.
\end{abstract} CIho 2291 and CIho 5098 and the winter barley cv. Nomini each have
Barley (Hordeum vulgare L.) is one of the most important crops worldwide. Net blotch (caused by the fungal pathogen Pyrenophora teres) is one of the most devastating foliar diseases of barley, causing yield losses ranging from a trace to $100 \%$ but typically ranging from 10 to $40 \%$ (7). The pathogen has two forms which cause different symptoms. $P$. teres $\mathrm{f}$. teres causes the net type of net blotch (NTNB) and P. teres f. maculata causes the spot type of net blotch (STNB). Symptoms of the NTNB form include net-like lesions of necrotic tissue extending longitudinally along the leaf, while STNB symptoms lack the net-like lesions and are smaller, and round or elliptical in nature (7). The NTNB isolate ND89-19 is one of the most widely virulent isolates in North America $(4,20)$.

Although chemical and cultural control methods may help reduce net blotch incidence, genetic resistance is the most efficient method of controlling the disease (9). Resistance to NTNB has been reported in several studies. The net blotch resistance genes $R p t l a, R p t 3 d$, Rpt 1 b, and Rpt $2 c$ were assigned to barley chromosomes $3 \mathrm{H}, 2 \mathrm{H}, 3 \mathrm{H}$, and $5 \mathrm{H}$, respectively, using trisomic analysis (1). The donor parents of these resistance genes are Tifang (Rptla), CIho 7584 (Rpt3d), and CIho 9819 (Rptlb and Rpt2c). An additional gene for NTNB resistance was mapped to chromosome $3 \mathrm{H}$ in cv. Igri and was assigned the temporary designation $P t, a$ until an allelism test is conducted with Rptla and Rpt $1 b$ to determine the uniqueness of these independently mapped genes (5). The resistant six-rowed barley 'Chevron' has a gene for NTNB resistance on chromosome $6 \mathrm{H}$ (7), tentatively designated Rpt until allelism tests are conducted with previously mapped NTNB resistance genes which have been reported on $6 \mathrm{H}(8,13)$.

Relatively few net blotch resistance sources have been extensively characterized, mapped, and successfully deployed in barleybreeding programs. The breeding line ND B112 (CIho 11531) has been reported as a source of resistance to both net blotch and spot blotch, caused by the fungal pathogen Cochliobolus sativus $(13,17)$. The six-rowed Canadian barley cv. Heartland is currently

Corresponding author: P. D. O’Boyle, E-mail: poboyle@betaseed.com

Accepted for publication 6 July 2010.

doi:10.1094/PDIS-02-10-0096

(C) 2011 The American Phytopathological Society being used as a net blotch resistance source in the University of Minnesota barley-breeding program $(11,14)$. Additional sources of net blotch resistance for use in barley-breeding programs were identified by screening 5,036 barley accessions in North Dakota (4). Eight accessions with broad resistance to multiple isolates of $P$. teres as well as $C$. sativus were identified as potential donors of resistance. These accessions included CIho 2291 (a spring-type barley from Virginia), CIho 5098 (plant introduction [PI] 83794, a spring-type barley from North Korea), and PI 434771 (a springtype barley from Quebec). The winter feed barley Nomini (PI 566929) also has been identified as a source of net blotch resistance (12).

The objectives of this research were to (i) compare the NTNB resistance of barley accessions CIho 2291, CIho 5098, and Nomini to identify loci conditioning novel resistance to net blotch; (ii) conduct a genetic analysis of $F_{2}$ populations derived from resistant-resistant $(\mathrm{R} \times \mathrm{R})$ and resistant-susceptible $(\mathrm{R} \times \mathrm{S})$ crosses and $\mathrm{R} \times \mathrm{S} \mathrm{F}_{2: 3}$ families to postulate gene number, mode of inheritance, and uniqueness for net blotch resistance; and (iii) identify $\mathrm{R} \times \mathrm{S} \mathrm{F}_{2}$ populations useful for linkage mapping of novel sources of net blotch resistance.

\section{Materials and Methods}

Plant materials. Five net-blotch-resistant parents and one susceptible parent were mated to produce a set of populations comprising pairwise combinations of the six parents. The net-blotch-resistant parents genetically characterized in this research included the primary sources CIho 5098, CIho 2291, and Nomini, and additional resistance sources ND B112 and ND 5883, which were included in allelism tests (Table 1). The net-blotch-susceptible parent was 'Hector'. Crosses among the six parents listed in Table 1 were made at Virginia Polytechnic Institute and State University (Virginia Tech) in 1998-99. $F_{1}$ seed was planted at the North Dakota Agricultural Experiment Station at Langdon, ND in 1999 to produce $F_{2}$ seed, which was kept in cold storage prior to use in these experiments. The $\mathrm{F}_{2: 3}$ seed was generated at Virginia Tech in the greenhouse.

Fungal culture and inoculum preparation. Fungal culture and inoculum preparation was conducted according to the procedures described by Steffenson et al. (13). The isolate used in inoculations was ND89-19, a widely virulent isolate from North Dakota with pathotype 1-2-6-7-10-13-16-18-25, based on disease response on 25 barley genotypes (20). For long-term storage of the P. teres f. 
teres isolate, cultures were prepared from a single-spore isolation, adhered to silica gel crystals, and stored at $4^{\circ} \mathrm{C}$ in glass vials. Inoculum preparation was initiated approximately 2 weeks prior to inoculations by placing several silica gel crystals containing conidia onto petri dishes containing V8 juice agar (18). Isolate ND89-19 were incubated at room temperature $\left(20\right.$ to $\left.25^{\circ} \mathrm{C}\right)$ for approximately 5 days under $12 \mathrm{~h}$ of fluorescent lighting $(14.3 \mu \mathrm{mol}$ $\mathrm{s}^{-1} \mathrm{~m}^{-2}$ ). After 5 days, cultures were transferred to new V8 juice agar plates and cultured under the same conditions for an additional 9 days prior to the inoculation of barley plants. Immediately prior to inoculation, petri dishes were scraped with a sterile plastic spatula after adding approximately 10 to $20 \mathrm{ml}$ of sterile distilled water. Because mycelia and media may clog inoculation equipment, the harvested conidial suspension was filtered through a single layer of cheesecloth (grade no. 40). After straining conidial suspensions, the inoculum was placed immediately on ice to inhibit spore germination. A hemacytometer was used to calculate and adjust inoculum concentration to approximately $2 \times 10^{4}$ conidia/ml. A single drop of Tween 20 per $100 \mathrm{ml}$ of inoculum was added after adjusting the concentration (13). After completion of the experiment, all fungal and rejected plant materials were steam sterilized for $3 \mathrm{~h}$ prior to disposal.

Growth chamber inoculations. Barley plants were grown in square plastic pots ( 6 by 6 by $5.5 \mathrm{~cm}$ ) with four seeds/pot and 32 pots/flat. The $\mathrm{F}_{2}$ population sizes ranged from 122 to 643 individuals and were planted in five to seven flats per population. Resistant and susceptible parents of each cross were included as check treatments along with the susceptible cv. Stander (PI 564743) as an additional check. Six pots containing one seed of each check were included in each flat and locations of the pots containing checks were randomized within each flat. Data for $\mathrm{F}_{2}$ plants derived from different $F_{1}$ plants were tested for homogeneity using a $\chi^{2}$ test prior to pooling data. The 267 Hector/Nomini $F_{2: 3}$ families were planted in a total of 122 flats and included 8 to 52 plants/family. The 112 Hector/CIho $2291 \mathrm{~F}_{2: 3}$ families were planted in a total of 22 flats and included 8 to 40 plants/family. The 124 Hector/CIho $5098 \mathrm{~F}_{2: 3}$ families were planted in a total of 32 flats and included 8 to 28 plants/family. Plants were fertilized approximately 10 days after planting with 20-20-20 (N- $\left.\mathrm{P}_{2} \mathrm{O}_{5}-\mathrm{K}_{2} \mathrm{O}\right)$ water-soluble fertilizer. Barley seedlings were inoculated at the two- to three-leaf stage (approximately 14 days after planting) with conidia suspended in water, using a glass atomizer and an air pump. Approximately 0.2 $\mathrm{ml}$ of inoculum suspension containing up to 2,000 conidia/ml was applied per plant. Inoculated seedlings were placed in complete darkness in a dew chamber (Percival Scientific, Perry, IA) at $20^{\circ} \mathrm{C}$ for approximately $24 \mathrm{~h}$ post inoculation. Following removal from the dew chamber, plants were placed in a growth chamber in which the temperature was maintained at approximately $20^{\circ} \mathrm{C}$ with $16 \mathrm{~h}$ of fluorescent light $\left(59.2 \mu \mathrm{mol} \mathrm{s} \mathrm{s}^{-1} \mathrm{~m}^{-2}\right)$. Evaluation of disease symptoms was recorded at approximately 9 to 14 days after inoculation, depending on which $\mathrm{F}_{2: 3}$ families were being screened and the development of disease symptoms on checks.

Classification of barley reaction to $P$. teres f. teres. Barley plants inoculated with $P$. teres f. teres were rated using the 1-to-10 scale described by Tekauz (16). Plants receiving a rating of 1 through 5 were categorized as resistant $(\mathrm{R})$ and plants receiving a rating of 6 through 10 were categorized as susceptible $(\mathrm{S})$. The scale accounts for the size, shape, and degree of chlorosis or necrosis associated with typical net blotch lesions on diseased barley plants. Resistant (ratings 1 to 3 ) disease reactions of NTNB consist of small, necrotic lesions with no chlorosis present, and moderately resistant (ratings 4 to 5) ones by small necrotic lesions with some necrotic transverse and longitudinal streaking. Moderately resistant reactions also can be accompanied by various degrees of chlorotic border around necrotic regions. Moderately susceptible (ratings 6 to 7) and susceptible (ratings 8 to 10) disease reactions are composed of larger, necrotic lesions with varying degrees of chlorotic border. For highly susceptible reactions types, the lesions will coalesce and, in extreme cases, necrosis of the entire leaf may occur (16). To test segregation ratios in $F_{2}$ and $F_{2: 3}$ populations, $\chi^{2}$ tests were used.

\section{Results}

Genetic analysis of $\mathbf{R} \times \mathbf{R} \mathbf{F}_{\mathbf{2}}$ progeny. Segregation patterns of progeny derived from crosses between the resistant parents Nomini and ND B112 (152R:10S), Nomini and ND 5883 (142R:12S), and Nomini and CIho 2291 (285R:11S) all fit a 15R:1S ratio (Table 2). This indicates that each of these parents possess a single independent dominant resistance gene governing net blotch resistance. Progeny derived from a cross between Nomini and the resistant parent CIho 5098 segregated 358R:4S, fitting a 63R:1S ratio and indicating that the progeny were segregating for three independent dominant resistance genes. Overall, segregation analysis of $\mathrm{R} \times \mathrm{R} \mathrm{F}_{2}$ populations that include Nomini indicates that it possesses a single dominant gene governing resistance to net blotch. The gene in Nomini is different from and independent of those in ND B112, ND 5883, and CIho 2291.

Progeny derived from a cross between CIho 2291 and ND B112 segregated 247R:5S, fitting a 63R:1S ratio and indicating segregation for three dominant resistance genes (Table 2). Progeny derived from a cross between CIho 2291 and CIho 5098 segregated 113R:9S and fit a 15:1 ratio. This indicated that the progeny were segregating for two dominant resistance genes. Overall, segregation analysis of $\mathrm{R} \times \mathrm{R} \mathrm{F}_{2}$ populations that include CIho 2291 indicates that it possesses a single dominant gene governing resistance to net blotch. The gene in CIho 2291 is different and independent of those in Nomini and CIho 5098.

Progeny derived from a cross between CIho 5098 and ND B112 segregated 129R:7S, fitting a 15:1 ratio (Table 2). This indicated that these parents have single independent dominant genes governing net blotch resistance. Overall, segregation analysis of $\mathrm{R} \times \mathrm{R} \mathrm{F}_{2}$ populations that include CIho 5098 indicates that it possesses a single dominant gene governing resistance to net blotch. The gene in CIho 5098 is different and independent of those in CIho 2291 and ND B112.

The resistant parents ND B112 and ND 5883 were included in allelism tests. $\mathrm{F}_{2}$ progeny derived from a cross between ND B112 and ND 5883 segregated 288R:32S, which was significantly differ-

Table 1. Pedigree, spike type, growth habit, and net blotch (caused by the fungal pathogen Pyrenophora teres) reaction of five resistant and one susceptible barley lines included as parents in a partial-diallel mating scheme used to derive $F_{2}$ and $F_{2: 3}$ progeny for characterization of net blotch resistance genes

\begin{tabular}{|c|c|c|c|c|}
\hline Line & Pedigree & $\begin{array}{l}\text { Spike } \\
\text { type }\end{array}$ & $\begin{array}{c}\text { Growth } \\
\text { habit }\end{array}$ & $\begin{array}{l}\text { Net blotch } \\
\text { reaction }^{\mathrm{a}}\end{array}$ \\
\hline ND B112 & 'Kindred'/CIho 7117-77 & Six-rowed & Spring & $\mathrm{R}(1-3)$ \\
\hline ND 5883 & ‘Clipper'/6/'Betzes'//CIho 5791/2*'Parkland'/3/“Betzes'/“Piroline'/4/“Akka'/5/“Centenial' & Two-rowed & Spring & $\mathrm{R}(2-5)$ \\
\hline Nomini & 'Boone'/'Henry'//VA77-12-41 b & Six -rowed & Winter & $\mathrm{R}(1-3)$ \\
\hline Clho 2291 & Selection from CIho 1326 & Two -rowed & Spring & $\mathrm{R}(1-4)$ \\
\hline CIho 5098 & Unknown & Six -rowed & Spring & $\mathrm{R}(1-5)$ \\
\hline Hector & Betzes/'Palliser' & Two -rowed & Spring & $\mathrm{S}(5-10)$ \\
\hline
\end{tabular}

${ }^{\mathrm{a}} \mathrm{R}=$ resistant (1 to 5) and $\mathrm{S}=$ susceptible (6 to 10) reactions to net blotch using the 1-to-10 scale developed by Tekauz (16), based on growth chamber inoculations. Numbers in parentheses represent the range of infection types for each parent on the 1-to-10 scale.

b VA 77-12-41 was derived from a composite of crosses including CIho 9623, CIho 9658, Clho 9708, and 'Atlas', each crossed to a 'Cebada Capa'/'Wong'//Awnletted 'Hudson' selection (12). 
ent from the expected 15R:1S ratio (Table 2). Overall, segregation analysis of $\mathrm{R} \times \mathrm{R} \mathrm{F}_{2}$ populations that include ND B112 and ND 5883 indicates that they each possess a single dominant gene governing resistance to net blotch. The gene in ND B112 is different and independent of those in Nomini, CIho 5098, and ND 5883. The gene in ND 5883 also is different and independent of the gene in Nomini.

Results of genetic analysis of $F_{2}$ progeny derived from $R \times R$ crosses indicate that Nomini has a single dominant gene governing net blotch resistance which differs from those in CIho 2291, ND B112, and ND 5883. Nomini and CIho 5098 putatively have the same single dominant net blotch resistance gene. Results of the genetic analysis of the $F_{2}$ progeny also indicate that CIho 2291 and ND B112 may share the same single dominant net blotch resistance gene.

Genetic analysis of $\mathbf{R} \times \mathbf{S} \mathbf{F}_{\mathbf{2}}$ progeny. The mode of inheritance and number of genes controlling net blotch resistance in five resistant parents was postulated using $\chi^{2}$ analysis of resistant versus susceptible $\mathrm{F}_{2}$ progeny derived from crosses of each resistant parent with the susceptible cv. Hector. ND B112 had an average infection type rating of 2 (ranging from 1 to 3 ) while Hector had an average rating of 7.5 (ranging from 5 to 10 ) for reaction to net blotch. The 134 Hector/ND B112 $\mathrm{F}_{2}$ progeny segregated 108R:26S, fitting a 3R:1S ratio (Table 3). This indicates that ND $\mathrm{B} 112$ has a single dominant gene for net blotch resistance.

ND 5883 had an average rating of 3.3 (ranging from 2 to 5) while Hector had an average rating of 8.2 (ranging from 7 to 9). The 144 Hector/ND $5883 \mathrm{~F}_{2}$ progeny segregated 113R:31S, which fit a $3 \mathrm{R}: 1 \mathrm{~S}$ ratio, indicating that ND 5883 has a single dominant gene for net blotch resistance (Table 3 )

Nomini had an average rating of 1.6 (ranging from 1 to 3 ) while Hector had an average rating of 8.8 (ranging from 7 to 10). The 236 Hector/Nomini $F_{2}$ progeny segregated 167R:69S, fitting a $3 \mathrm{R}: 1 \mathrm{~S}$ ratio. This indicates that Nomini has a single dominant gene for seedling resistance to net blotch (Table 3 ).

The resistant parent CIho 2291 had an average rating of 1.9 (ranging from 1 to 4) while the susceptible parent Hector had an average rating of 8 (ranging from 7 to 9). The 643 Hector/CIho $2291 \mathrm{~F}_{2}$ progeny segregated $489 \mathrm{R}: 154 \mathrm{~S}$, fitting a 3R:1S ratio. This indicates that CIho 2291 has a single dominant gene for resistance net blotch (Table 3).

The resistant parent CIho 5098 had an average rating of 2.5 (ranging from 1 to 5) while the susceptible parent Hector had an average rating of 7.5 (ranging from 6 to 9). The $252 \mathrm{Hec}-$ tor/CIho5098 $\mathrm{F}_{2}$ progeny segregated 195R:57S, fitting a 3R:1S ratio. This indicates that CIho 5098 has a single dominant gene for seedling resistance to $P$. teres isolate ND89-19 (Table 3).

Results of the genetic analysis of $\mathrm{F}_{2}$ progeny derived from $\mathrm{R} \times \mathrm{S}$ crosses indicate that ND B112, ND 5883, Nomini, CIho 2291, and CIho 5098 each have a single dominant gene governing resistance to net blotch. Overall, these results confirm those from genetic analysis of progeny derived from $\mathrm{R} \times \mathrm{R}$ crosses.

Genetic analysis of $\mathbf{R} \times \mathbf{S} \mathbf{F}_{2: 3}$ progeny. A $\chi^{2}$ analysis of 267 Hector $\times$ Nomini $F_{2: 3}$ families (Table 4) confirmed data from $F_{2}$ populations that Nomini has a single dominant gene for net blotch resistance. The $267 \mathrm{~F}_{2: 3}$ families were classified as 61 homozygous resistant lines, 128 heterozygous lines (segregating 3R:1S), and 78 homozygous susceptible lines. These data fit the expected 1:2:1 genotypic ratio for the segregation of a single dominant gene conferring resistance to net blotch.

A $\chi^{2}$ analysis of Hector $\times$ CIho $2291 \mathrm{~F}_{2: 3}$ families (Table 4) confirmed data from $\mathrm{F}_{2}$ populations that CIho 2291 has a single dominant gene for net blotch resistance. The $112 \mathrm{~F}_{2: 3}$ families were classified as 30 homozygous resistant lines, 52 heterozygous lines (segregating 3R:1S), and 30 homozygous susceptible lines. These data fit the expected 1:2:1 genotypic ratio for the segregation of a single dominant gene conferring resistance to net blotch.

A $\chi^{2}$ analysis of Hector $\times$ CIho $5098 \mathrm{~F}_{2: 3}$ families (Table 4) confirmed data from $\mathrm{F}_{2}$ populations that CIho 5098 has a single dominant gene for net blotch resistance. The $124 \mathrm{~F}_{2: 3}$ families were classified as 33 homozygous resistant lines, 59 heterozygous lines (segregating 3R:1S), and 32 homozygous susceptible lines. These data fit the expected 1:2:1 genotypic ratio for the segregation of a single dominant gene conferring resistance to net blotch.

\section{Discussion}

Efficient use of disease resistance sources in plant breeding programs is dependent upon successful characterization of the resis-

Table 2. A $\chi^{2}$ analysis of the number of genes controlling resistance to net blotch (caused by Pyrenophora teres) in five resistant barley parents ${ }^{\mathrm{a}}$

\begin{tabular}{|c|c|c|c|c|c|c|}
\hline Parent 1 & Parent 2 & $\mathbf{R}^{\mathbf{b}}$ & $\mathbf{S}^{\mathbf{b}}$ & Ratio $^{c}$ & $\chi^{2 \mathrm{~d}}$ & $P$ value \\
\hline Nomini & ND B112 & 152 & 10 & $15: 1$ & 0.0 & 0.97 \\
\hline Nomini & ND 5883 & 142 & 12 & $15: 1$ & 0.6 & 0.43 \\
\hline Nomini & CIho 2291 & 285 & 11 & $15: 1$ & 3.2 & 0.07 \\
\hline Nomini & CIho 5098 & 358 & 4 & $63: 1$ & 0.5 & 0.48 \\
\hline CIho 2291 & ND B112 & 247 & 5 & $63: 1$ & 0.3 & 0.59 \\
\hline CIho 2291 & CIho 5098 & 113 & 9 & $15: 1$ & 0.3 & 0.60 \\
\hline CIho 5098 & ND B112 & 129 & 7 & $15: 1$ & 0.3 & 0.59 \\
\hline ND B112 & ND 5883 & 288 & 32 & $15: 1$ & $7.7 *$ & 0.005 \\
\hline
\end{tabular}

${ }^{a}$ Each population consisted of $\mathrm{F}_{2}$ progeny derived from resistant-resistant parental crosses.

${ }^{\mathrm{b}} \mathrm{R}=$ number of $\mathrm{F}_{2}$ progeny which received a rating of 1 to 5 and $\mathrm{S}=$ number of $\mathrm{F}_{2}$ progeny which received a rating of 6 to 10 using the scale described by Tekauz (16) in response to P. teres f. teres isolate ND89-19.

${ }^{c}$ Ratio used in $\chi^{2}$ test where 15:1 indicates segregation of two independent dominant genes and 63:1 indicates segregation of three independent dominant genes.

d Asterisk (*) indicates significance at $P \leq 0.01$

Table 3. A $\chi^{2}$ analysis of the number of genes controlling resistance to net blotch (caused by Pyrenophora teres) in five resistant barley parents ${ }^{\mathrm{a}}$

\begin{tabular}{|c|c|c|c|c|c|c|}
\hline Parent 1 & Parent 2 & $\mathbf{R}^{\mathbf{b}}$ & $\mathbf{S}^{\mathbf{b}}$ & Ratio $^{c}$ & $\chi^{2}$ & $P$ value \\
\hline Hector & ND B112 & 108 & 26 & $3: 1$ & 2.2 & 0.13 \\
\hline Hector & ND 5883 & 113 & 31 & $3: 1$ & 0.9 & 0.33 \\
\hline Hector & Nomini & 167 & 69 & $3: 1$ & 2.3 & 0.13 \\
\hline Hector & CIho 2291 & 489 & 154 & $3: 1$ & 0.4 & 0.54 \\
\hline Hector & CIho 5098 & 195 & 57 & $3: 1$ & 0.8 & 0.38 \\
\hline
\end{tabular}

${ }^{a}$ Each population consisted of $\mathrm{F}_{2}$ progeny derived from resistant-susceptible parental crosses.

${ }^{\mathrm{b}} \mathrm{R}=$ number of $\mathrm{F}_{2}$ progeny which received a rating of 1 to 5 and $\mathrm{S}=$ number of $\mathrm{F}_{2}$ progeny which received a rating of 6 to 10 using the scale described by Tekauz (16) in response to P. teres f. teres isolate ND89-19.

${ }^{\mathrm{c}}$ Ratio used in $\chi^{2}$ test where 3:1 indicates segregation of one dominant gene, 15:1 indicates segregation of two independent dominant genes, and 63:1 indicates segregation of three independent dominant genes. 
tance gene or genes carried by such sources. Breeding for disease resistance may be complicated by pathotype variability in the pathogen. Moderate to high variability for virulence can occur among isolates of $P$. teres $\mathrm{f}$. teres $(15,17)$, suggesting that pyramiding of novel resistance genes from multiple sources may be required to develop barley cultivars having effective, broad, and durable resistance $(3,6,7,10,20)$.

In the current study, two recently identified NTNB-resistant barley lines (CIho 5098 and CIho 2291) and the resistant winter barley cv. Nomini were characterized for their potential use as NTNB resistance sources in barley-breeding programs. These three resistance sources were compared with each other and with two previously described resistance sources, ND B112 and ND 5883 $(13,19)$, using a partial-diallel mating scheme, which included the susceptible parent Hector. A combination of $\mathrm{F}_{2}$ and $\mathrm{F}_{2: 3}$ progeny derived from crosses between the six parents were used to determine novelty of the resistance genes in each of the resistant parents as well as to postulate gene number and mode of inheritance.

Genetic analysis of $\mathrm{F}_{2}$ populations indicated that ND B112 has one dominant gene for seedling resistance to NTNB (Tables 2 and 3 ). This resistance gene segregated independently and is different from those in Nomini, CIho 5098, and ND 5883 (Table2). Genetic analysis of $F_{2}$ populations also indicated that ND 5883 has a single dominant gene for NTNB resistance. This gene was novel compared with the resistance genes in ND B112, Nomini, CIho 5098, and CIho 2291 (Tables 2 and 3).

Genetic analysis of $F_{2}$ progeny derived from a cross between Nomini and CIho 5098 indicated that three independent, dominant genes for resistance to NTNB were segregating in this population (Table 2). However, other $\mathrm{F}_{2}$ data overwhelmingly indicate that both CIho 5098 and Nomini have the same single dominant resistance gene (Tables 3 and 4). An alternative explanation for this discrepancy, given the small number of susceptible individuals in the Nomini $\times$ CIho $5098 \mathrm{~F}_{2}$ population, is that the four susceptible individuals were either misclassified or the result of a seed mixture. The interpretation of this scenario is that Nomini and CIho 5098 have the same dominant gene for NTNB resistance. Genetic analysis of additional $\mathrm{F}_{2}$ populations indicated that the resistance gene or genes in CIho 5098 differ from those in CIho 2291 and ND B112 (Table 2). Genetic analysis of $F_{2}$ and $F_{2: 3}$ populations indicated that NTNB resistance in CIho 2291 is conditioned by one dominant gene, which differs from the NTNB resistance genes in Nomini and CIho 5098 (Tables 2-4). Genetic analysis of $F_{2}$ progeny derived from a cross between ND B112 and CIho 2291 indicated that three independent, dominant genes for resistance to NTNB were segregating in this population (Table 2). Other $F_{2}$ data, however, strongly indicate that both ND B112 and CIho 2291 have a single dominant resistance gene (Tables 3 and 4). The small number of susceptible individuals (five) in the ND B112 $\times$ CIho $2291 \mathrm{~F}_{2}$ population likely were misclassified or the result of a seed mixture. The implication of this scenario is that ND B112 and CIho 2291 have the same dominant gene for NTNB resistance.

The observation of a small number of susceptible individuals in the Nomini $\times$ CIho 5098 and ND B112 $\times$ CIho $2291 \mathrm{~F}_{2}$ populations, although likely the result of misclassification, suggest that alternative explanations are possible. One alternative is that a modifying gene required for the expression of disease resistance is linked to the NTNB resistance gene in Nomini and CIho 5098, and a similar modifying gene is linked to the resistance gene in ND B112 and CIho 2291. In this situation, the modifying genes may be very closely linked to the major resistance gene; however, infrequent recombination could occur, resulting in a few susceptible individuals. These modifying genes could operate in a similar manner to rpg4 which, when expressed in barley genotypes also expressing Rpg5, confers resistance to stem rust (Puccinia graminis f. sp. tritici) race TTKSK (a.k.a. Ug99) (2).

In conclusion, results of these genetic experiments have several implications for utilization of net blotch resistance genes carried by resistant parents included in this study. The resistant barley lines Nomini, CIho 5098, and CIho 2291 all have a single dominant NTNB resistance gene. The monogenic and dominant nature of net blotch resistance in these sources should allow for easy transfer of resistance genes into high-yielding breeding lines with favorable agronomic and end-use quality traits in cultivar-development programs. Also, the discovery that Nomini and CIho 5098 have the same net blotch resistance gene affords breeders wishing to use this resistance gene with a choice of donor parents. Spring barley breeders can use CIho 5098 whereas winter barley breeders can use Nomini, thus avoiding crosses between barley parents having spring and winter growth habits. The resistance gene in Nomini or CIho 5098 could be pyramided with the resistance gene in CIho 2291 (or ND B112). ND B112 has been used extensively as a source of durable spot blotch resistance in Upper Midwest barley cultivars but is also known to possess a high level of net blotch resistance. Unfortunately, the net blotch resistance from ND B112 was apparently not transferred to these cultivars, as most are susceptible (13). The resistance gene in ND 5883 could also be pyramided if a wider spectrum of disease resistance is desired. This strategy has been suggested as a method of ensuring the durability of resistance as well as providing resistance against a wide spectrum of $P$. teres isolates (3). The resistant parents Nomini, CIho 5098, and CIho 2291 are all potential parents for linkage mapping of single dominant genes conditioning NTNB resistance.

\section{Acknowledgments}

We thank R. Dill-Macky (University of Minnesota) for lending her expertise to the fungal culture and inoculation procedures. ND89-19 was utilized under APHIS permit P526P-07-04647.

\section{Literature Cited}

1. Bockelman, H. E., Sharp, E. L., and Eslick, R. F. 1977. Trisomic analysis of genes for resistance to scald and net blotch in several barley cultivars. Can. J. Bot. 55:2142-2148.

2. Brueggeman, R., Steffenson, B. J., and Kleinhofs, A. 2009. The rpg4/RPG5 stem rust resistance locus in barley. Cell Cycle 8:1-5.

3. Douiyssi, A., Rasmusson, D. C., and Roelfs, A. P. 1998. Responses of barley cultivars and lines to isolates of Pyrenophora teres. Plant Dis. 82:316-321.

4. Fetch, T. G., Jr., Steffenson, B. J., Bockelman, H. E., and Wesenber, D. M. 2008. Spring barley accessions with dual spot blotch and net blotch resistance. Can. J. Plant Pathol. 30:534-542.

5. Graner, A., Foroughi-Wehr, B., and Tekauz, A. 1996. RFLP mapping of a gene in barley conferring resistance to net blotch (Pyrenophora teres). Euphytica 91:229-234.

6. Gupta, S., Loughman, R., Platz, G. J., and Lance, R. C. M. 2003. Resistance

Table 4. A $\chi^{2}$ analysis of the number of genes controlling resistance to net blotch (caused by Pyrenophora teres) in $\mathrm{F}_{2: 3}$ families of three resistant-susceptible barley crosses

\begin{tabular}{|c|c|c|c|c|c|c|}
\hline \multirow[b]{2}{*}{ Cross } & \multicolumn{3}{|c|}{ No. of $F_{2: 3}$ families } & \multirow[b]{2}{*}{ Ratio $^{\mathbf{d}}$} & \multirow[b]{2}{*}{$\chi^{2}$} & \multirow[b]{2}{*}{$P$ value } \\
\hline & $\mathbf{R}^{\mathbf{a}}$ & $\mathbf{H}^{\mathbf{b}}$ & $\mathbf{S}^{\mathbf{c}}$ & & & \\
\hline Hector/Nomini & 61 & 128 & 78 & $1: 2: 1$ & 2.6 & 0.27 \\
\hline Hector/CIho 2291 & 30 & 52 & 30 & $1: 2: 1$ & 0.6 & 0.75 \\
\hline Hector/CIho 5098 & 33 & 59 & 32 & $1: 2: 1$ & 0.3 & 0.86 \\
\hline
\end{tabular}

${ }^{a}$ Number of $\mathrm{F}_{2: 3}$ families in which all seedlings tested received a rating of 1 to 5 using the scale described by Tekauz (16) in response to $P$. teres $\mathrm{f}$. teres isolate ND89-19.

${ }^{b}$ Number of $F_{2: 3}$ families for which seedlings segregated 3R:1S, indicating that the $F_{2}$ plant from which they were derived was heterozygous.

${ }^{c}$ Number of $\mathrm{F}_{2: 3}$ families which received a rating of 6 to 10 in response to P. teres f. teres isolate ND89-19.

d Ratio used in $\chi^{2}$ test; 1:2:1 indicates segregation of one dominant gene. 
in cultivated barleys to Pyrenophora teres f. teres and prospects of its utilisation in marker identification and breeding. Aust. J. Agric. Res. 54:13791386.

7. Ma, Z. Q., Lapitan, N. L. V., and Steffenson, B. 2004. QTL mapping of net blotch resistance genes in a doubled-haploid population of six-rowed barley. Euphytica 137:291-296.

8. Manninen. O., Kalendar, R., Robinson, J., and Schulman, A. H. 2000. Application of BARE-1 retrotransposon markers to the mapping of a major resistance gene for net blotch in barley. Mol. Gen. Genet. 264:325-334.

9. Mathre, D. E. 1997. Net blotch. Pages 28-31 in: Compendium of Barley Diseases, 2nd ed. D. E. Mathre, ed. American Phytopathological Society, St. Paul, MN.

10. Raman, H., Platz, G. J., Chalmers, K. J., Raman, R., Read, B. J., Barr, A. R., and Moody, D. B. 2003. Mapping of genomic regions associated with net form of net blotch resistance in barley. Aust. J. Agric. Res. 54:1359-1367.

11. St. Pierre, S., Gustus, C., Steffenson, B., Dill-Macky, R., and Smith, K. P. 2010. Mapping net form net blotch and Septoria speckled leaf blotch resistance loci in barley. Phytopathology 100:80-84.

12. Starling, T. M., Griffey, C. A., Price, A. M., Roane, C. W., Sisson, W. L., and Brann, D. E. 1994. Registration of 'Nomini' barley. Crop Sci. 34:300.

13. Steffenson, B. J., Hayes, P. M., and Kleinhofs, A. 1996. Genetics of seed- ling and adult plant resistance to net blotch (Pyrenophora teres f. teres) and spot blotch (Cochliobolus sativus) in barley. Theor. Appl. Genet. 92:552558.

14. Steffenson, B. J., and Smith, K. P. 2006. Breeding barley for multiple disease resistance in the Upper Midwest region of the USA. Czech. J. Genet. Plant Breed. 42:79-85.

15. Steffenson, B. J., and Webster, R. K. 1992. Quantitative resistance to Pyrenophora teres f. sp. teres in barley. Phytopathology 82:407-411.

6. Tekauz, A. 1985. A numerical scale to classify reactions of barley to Pyrenophora teres. Can. J. Plant Pathol. 7:181-183.

17. Tekauz, A. 1990. Characterization and distribution of pathogenic variation in Pyrenophora teres f. teres and P. teres f. maculata from western Canada. Can. J. Plant Pathol. 12:141-148.

18. Tuite, J., ed. 1969. Plant Pathological Methods. Burgess Publishing Co., Minneapolis, MN.

19. Wilcoxson, R. D., Rasmusson, D. C., and Miles, M. R. 1990. Development of barley resistant to spot blotch and genetics of resistance. Plant Dis 74:207-210.

20. Wu, H. L., Steffenson, B. J., Li, Y., Oleson, A. E., and Zhong, S. 2003. Genetic variation for virulence and RFLP markers in Pyrenophora teres. Can. J. Plant Pathol. 25:82-90. 